\title{
Richness of gall-inducing insects in the tropical dry forest (caatinga) of Pernambuco
}

\author{
Jean Carlos Santos ${ }^{1}$, Jarcilene Silva de Almeida-Cortez ${ }^{2}$ \& G. Wilson Fernandes ${ }^{3}$
}

\author{
'Instituto de Biologia, Universidade Federal de Uberlândia, Caixa Postal 593, 38400-902 Uberlândia-MG, Brazil. jcsantos@inbio.ufu.br \\ ${ }^{2}$ Departamento de Botânica, Universidade Federal de Pernambuco, Av. Prof. Moraes Rêgo s/número, 50670-901 Recife-PE, Brazil. \\ cortez_jarcy@yahoo.com \\ ${ }^{3}$ Ecologia Evolutiva e Biodiversidade, Universidade Federal de Minas Gerais, 30161-970 Belo Horizonte-MG, Brazil. gw.fernandes@gmail.com
}

\begin{abstract}
Diversity of gall-inducing insects in the tropical dry forest (caatinga) of Pernambuco. We report on the richness of galling insects in the vegetation of caatinga of Pernambuco state, Brazil. We recorded 64 different types of galls collected primarily from leaves and stems of 48 species of host plants belonging to 17 families and 31 genera. The most common gall morphological types were spheroid and discoid, glabrous, predominantly green and with one chamber. The main gall inducing taxon was the Cecidomyiidae (Diptera). The results of this study contribute to existing knowledge of galling insect and host-plant diversity in caatinga.
\end{abstract}

KEYWORDS. Cecidomyiidae; host plants; insect galls; insect herbivore; species richness.

RESUMO. Diversidade de insetos indutores de galhas na floresta tropical seca (caatinga) de Pernambuco. Este artigo reporta sobre a riqueza de insetos galhadores na vegetação de caatinga de Pernambuco, Brasil. Foram registrados 64 diferentes tipos de galhas coletadas principalmente em folhas e caules de 48 espécies de plantas hospedeiras pertencentes a 17 famílias e 31 gêneros. Os tipos morfológicos de galhas mais comuns foram esferóide e discóides, glabro, predominantemente verde e com uma câmara. O principal táxon indutor de galhas foi Cecidomyiidae (Diptera). Os resultados deste estudo contribuem para o conhecimento da diversidade de insetos galhadores e planta-hospedeira na caatinga.

PALAVRAS-CHAVE. Cecidomyiidae; galhas entomógenas; insetos herbívoros; plantas hospedeiras; riqueza de espécies.

Gall-inducing insects are very rich in species around the word and the latest global richness estimates the existence between 21,000 to 211,000 species, with an average of 132,930 species (Espírito-Santo \& Fernandes 2007). In Brazil, studies addressing the richness of galling insects have been increasing in several ecosystems, such as Atlantic forest (e.g., Fernandes et al. 2001; Mendonça 2007; Moreira et al. 2007), restinga (Atlantic Coast restingas) (see Oliveira \& Maia 2005), wetlands (Pantanal) (Julião et al. 2002; Julião et al. 2004), Amazon rain forest (Julião et al. 2005), but most studies were done in the cerrado (savanna) (e.g., Fernandes et al. 1997; Gonçalves-Alvim \& Fernandes 2001a, b; Lara et al. 2002; Urso-Guimarães et al. 2003; Maia \& Fernandes 2004; Urso-Guimarães \& Scarelli-Santos 2006; Carneiro et al. 2009b; Coelho et al. 2009). In these ecosystems, the highest species richness of galling insects is concentrated in the rupestrian fields and in the cerrado (savanna) vegetation of southeastern Brazil (Fernandes \& Price 1988; Lara \& Fernandes 1996). Up to date, the knowledge on the other many tropical vegetations of Brazil is scanty, such as in the seasonally dry tropical forests of northeastern region.

The caatinga, a Brazilian seasonally dry tropical forest, is the fourth largest ecosystem in Brazil and exclusively of Brazil. This tropical dry forest occupies an area of 840,000 $\mathrm{km}^{2}$, which represented almost $70 \%$ of the northeastern region and $10 \%$ of the territory in nine Brazilian states (Piauí,
Ceará, Rio Grande do Norte, Paraíba, Alagoas, Sergipe, Bahia, Minas Gerais, and Pernambuco) (Castelletti et al. 2003). In the state of Pernambuco, the caatinga is the largest ecosystem, occupying an area of approximately $85 \%$ of the territory. Less than $1 \%$ of the caatinga (only 11 reserves) is protected by conservation areas (Leal et al. 2005). The caatinga is a semi-arid vegetation (tropical dry forest), characterized by a deciduous forest, shrub to tree vegetation of extreme drought, which plants undergo severe water shortage during a large portion of the year that lasts from March to October. The rains in the caatinga are irregular throughout the year, the low annual rainfall distribution (500 to $750 \mathrm{~mm}$ year ${ }^{-1}$ ) occurs only during three to five months, with a water deficit during most months, and the annual average temperature is between 23 and $27^{\circ} \mathrm{C}$ (see Prado 2003). For many years, the caatinga was considered a region of poor species diversity, but recent studies have demonstrated that it supports a rich flora with a high degree of endemism of both plants and animals (see Leal et al. 2005). Despite its great biological importance, there are exceedingly few ecological studies in the caatinga, especially to insects (J. C. Santos, pers. comm.). For the first time, we report on the richness of galling insects in this vegetation in an attempt to broaden our knowledge of galling species diversity in the seasonally tropical dry forests of the Americas. 


\section{MATERIAL AND METHODS}

Study site. This study was conducted in seven private areas of caatinga (municipalities: Alagoinha, Custódia, Pombos, Bodocó, Serrita, Pesqueira, Salgueiro and Parnamirim), one national park (Parque Nacional Vale do Catimbau - Buíque municipality), and two ecological stations (Universidade Federal Rural de Pernambuco - Serra Talhada municipality and Instituto Agronômico de Pernambuco - Caruaru municipality); all sites located in Pernambuco state, Brazil. These areas were chosen to cover the maximum of the longitudinal variability of the vegetation of the caatinga in the state of Pernambuco and to avoid concentration of sampling in a single area (pseudo-replication), with Pombos the area closest to the coast and Bodocó the farthest area (Fig. 1).

Sampling galling insects richness. The caatinga was investigated for galls over a period of seven months from February to August of 2008, covering part of the rainy season and part of the dry season. This period was chosen because the plants had fully expanded leaves. In each site, galling insect richness were sampled by two people following the adapted methodology of random walking (Julião et al. 2002; Fernandes \& Negreiros 2006; Coelho et al. 2009), where instead of an hour, we spent three hours in each area. To maximize the sampling of richness, a distance of at least 500 meters was established among the sites sampled inside the areas (Fernandes \& Price 1988). All plant organs were investigated, and each gall and host plants (up to 3 meters height) found were collected, packed in plastic bags, and then taken to a laboratory for photographic registration and description of the external morphology. Host plants were classified into morphospecies in the field, and later at the species level by specialist before included in the Herbarium UFPE (Universidade Federal de Pernambuco). The classification of species of host plants followed the system proposed by Angiosperm Phylogeny Group II (APG II 2003), and the authors and scientific host plant names were checked in Missouri Botanical Garden website http://mobot.mobot.org/W3T/Search/ classicvast.html.

We identified gall morphospecies based upon their external morphology in combination with their host plant species. In general, 95\% species of insect induce a gall on a specific tissue of a certain plant species (Carneiro et al. 2009a). Therefore, in this article, we consider the gall morphotypes as true species (see also Coelho et al. 2009). Galls were characterized as reported by Fernandes \& Price (1988): host plant species, number of types of galls by host plant, type of host tissue attacked, shape of galls, color of galls, presence or absence of pubescence, and number of chambers in the gall, occurrence on the galled organ: isolated or grouped/coaslescent. We chose to present only a list with the probable inducers of gall maker because many galls were naturally damaged, or without the presence of the inductor or with inductor parasited. The use of morphospecies to represent the galling species richness is widely accepted in the literature and it has been used in several studies in different ecosystems (e.g., Price et al. 1998; Cuevas-Reyes et al. 2004; Fernandes \& Negreiros 2006; Moreira et al. 2007; Coelho et al. 2009; see also Carneiro et al. 2009a).

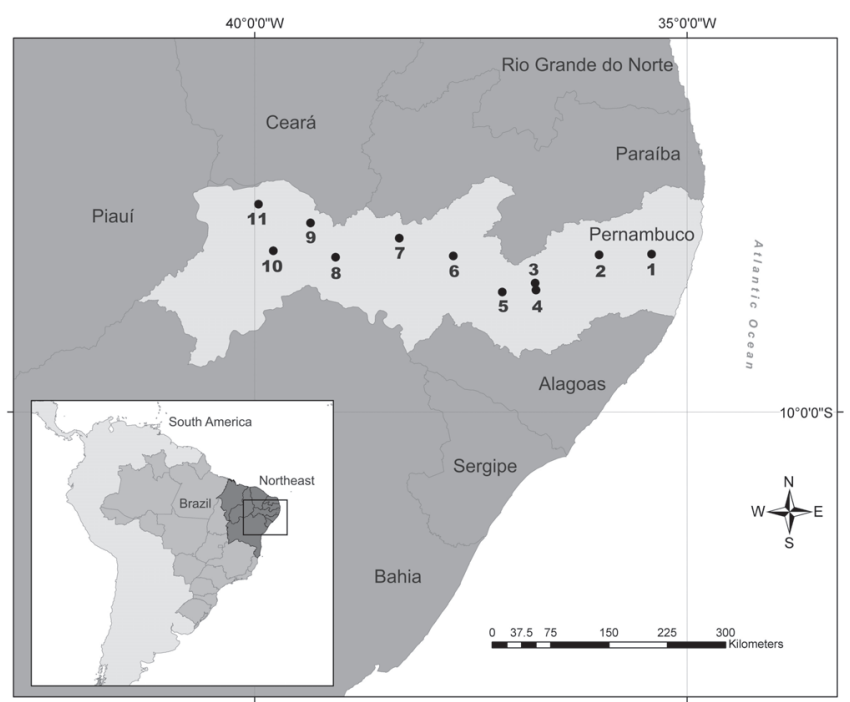

Fig. 1. Location of the studied sites (number) in Pernambuco state (detail), northeast region (light grey) of Brazil (dark grey). 1- Pombos; 2 - Caruaru; 3 - Pesqueira; 4 - Alagoinha; 5 - Buíque; 6 - Custódia; 7 - Serra Talhada; 8 - Salgueiro; 9 - Serrita, 10 - Parnamirim and 11 - Bodocó.

\section{RESULTS}

We found 64 morphologically distinct types of insect galls in the caatinga of Pernambuco. These galls were found in 48 species of host plants from 17 families and 31 genera (Table I, Figs. 2-5). The richness of galling insects was greater in the Vale do Catimbau (33 morphotypes) followed by Serra Talhada (11 morphotypes), Parnamirim (nine morphotypes), Caruaru (eight morphotypes), Alagoinhas, Custódia, Pombos and Bodocó each with six morphotypes, Serrita (five morphotypes), Pesqueira (three morphotypes) and Salgueiro with two morphotypes. The majority of galls induced by insects belongs to the family Cecidomyiidae (89\%) followed by Coleoptera $(5 \%)$, Heteroptera $(2 \%)$ and five percent were undetermined. The host plant families that had a greater number of species of galls were: Fabaceae (23.44\%), Euphorbiaceae (14.06\%), and Boraginaceae, Malpighiaceae and Myrtaceae with 6.25\% each. When we consider the host plant species by family, we found almost the same pattern: Fabaceae (16.67\%), Euphorbiaceae (16.67\%), and Sapindaceae, Malpighiaceae and Myrtaceae with $8.33 \%$ each. The genera with the greatest number of morphospecies of galls were: Croton (four species), Cnidoscolus (three species), and, Bauhinia and Byrsonima with two species each. Most galls were induced on the leaves (73.44\%), stems (20.31\%), and on apical buds (6.25\%). The most frequent shape of galls was spheroid (32.81\%), followed by discoid $(25.00 \%)$. Seventy-seven percent of galls were glabrous, $78.13 \%$ were predominantly green, while $73.44 \%$ did not form clusters. 


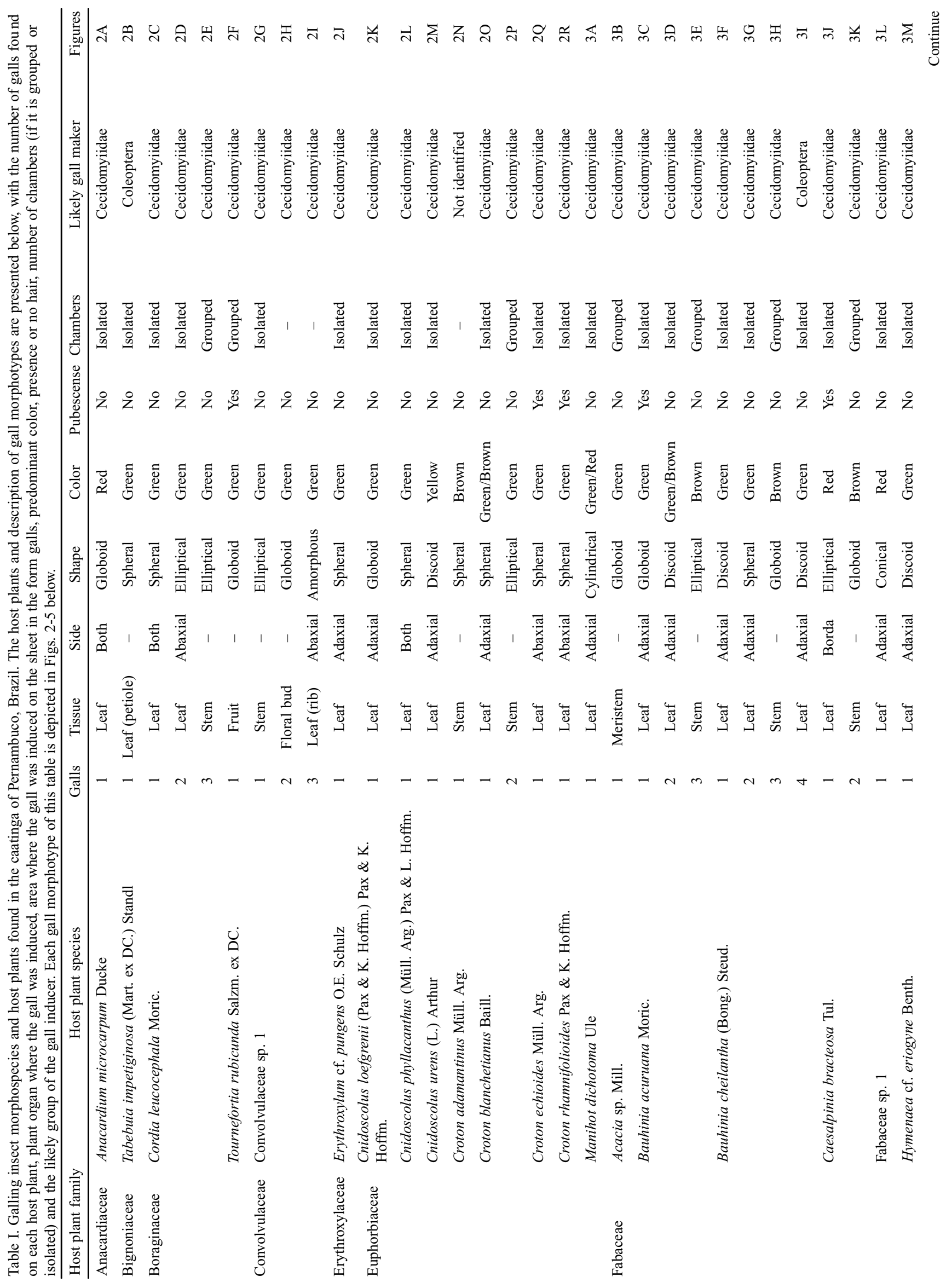




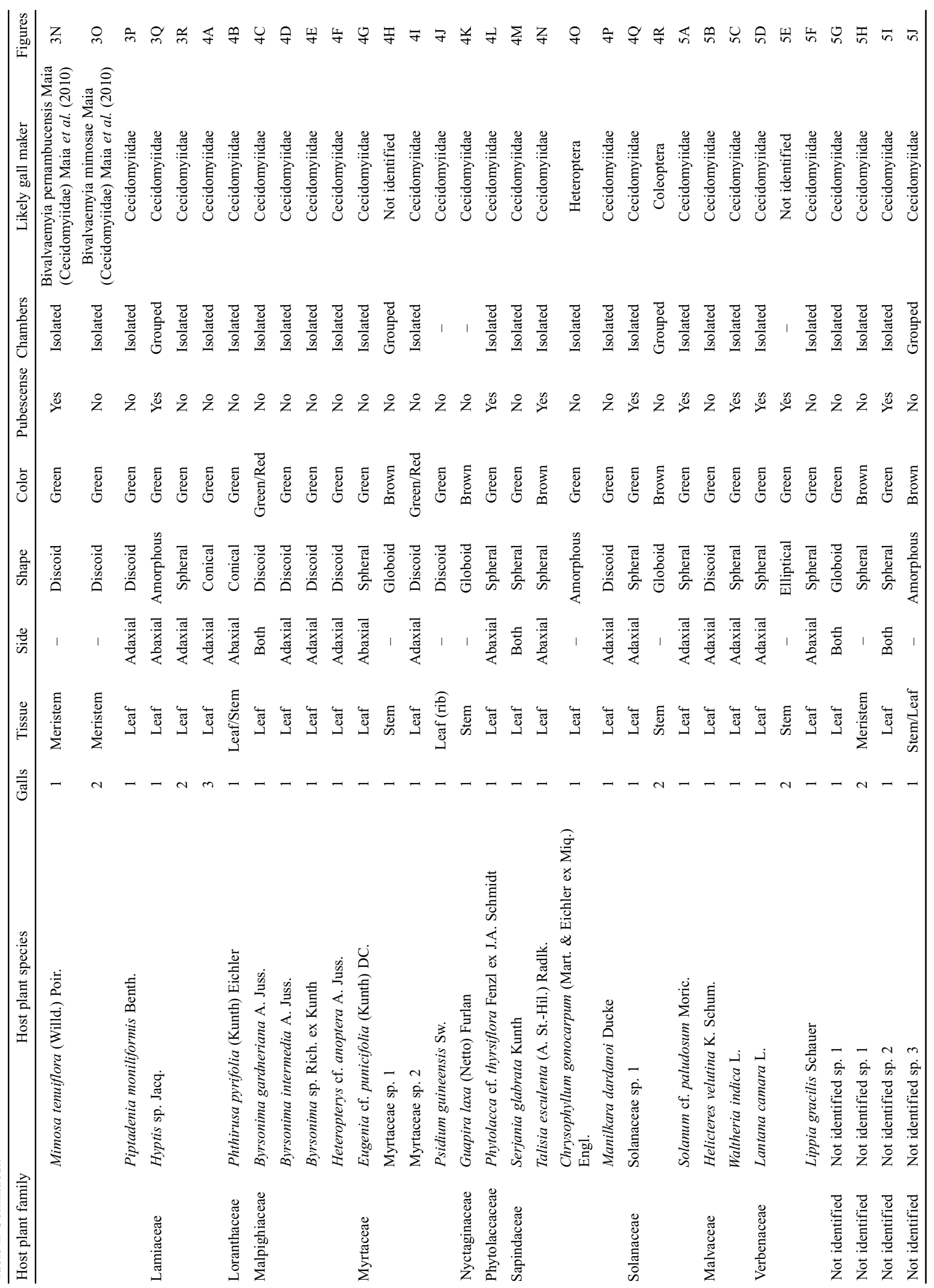



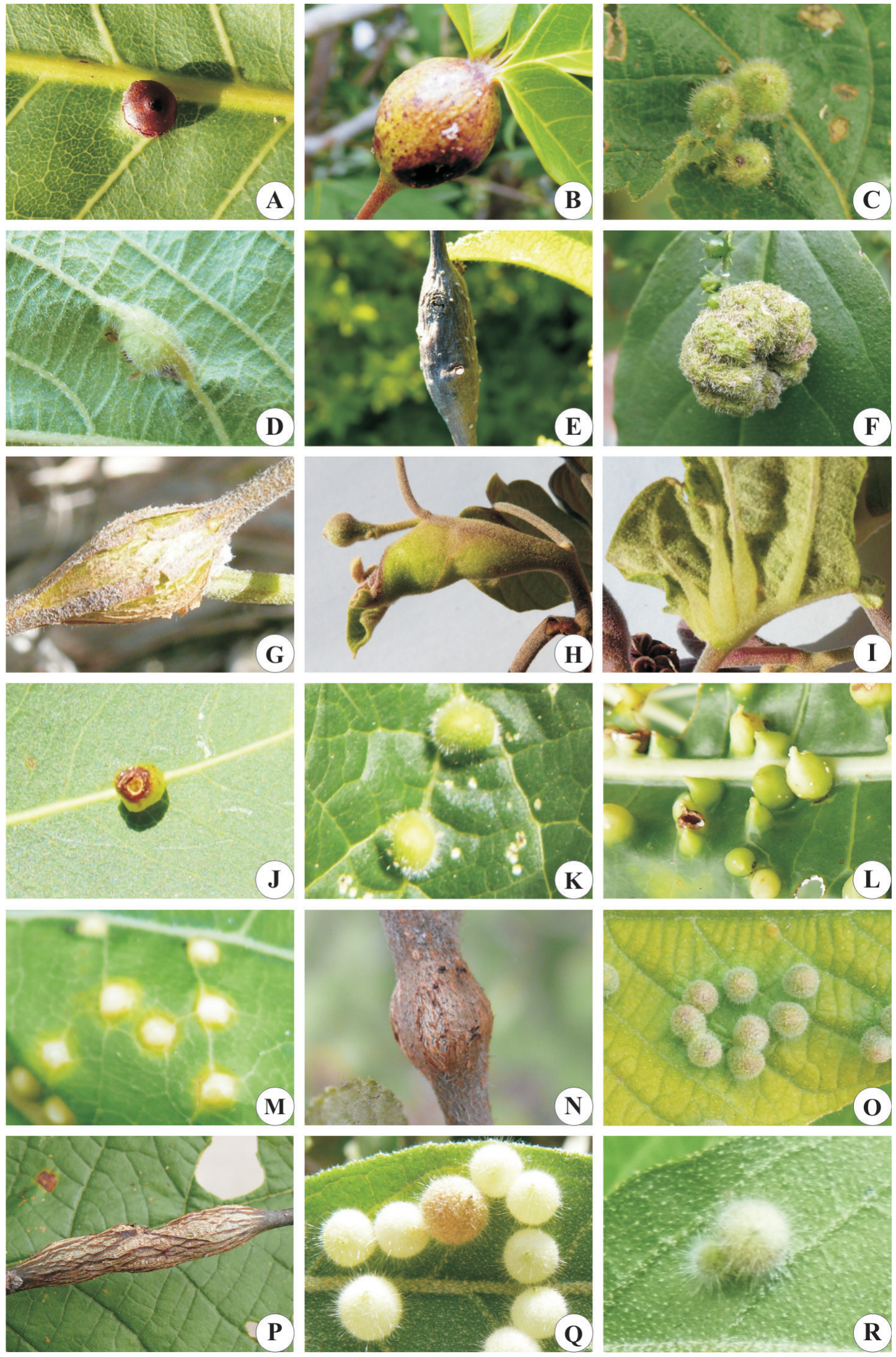

Fig. 2. Galling insect morphospecies in caatinga of Pernambuco, Brazil. A - Anacardium microcarpum; B - Tabebuia impetiginosa; C-E - Cordia leucocephala; F - Tournefortia rubicunda; G-I - Convolvulaceae sp. 1; J - Erythroxylum cf. pungens; K - Cnidoscolus loefgrenii; L - Cnidoscolus phyllacanthus; M - Cnidoscolus urens; $\mathrm{N}$ - Croton adamantinus; O-P - Croton blanchetianus; $\mathrm{Q}$ - Croton echioides; $\mathrm{R}$ - Croton rhamnifolioides. For host plant identification and gall morphotypes description, see also Table I. 

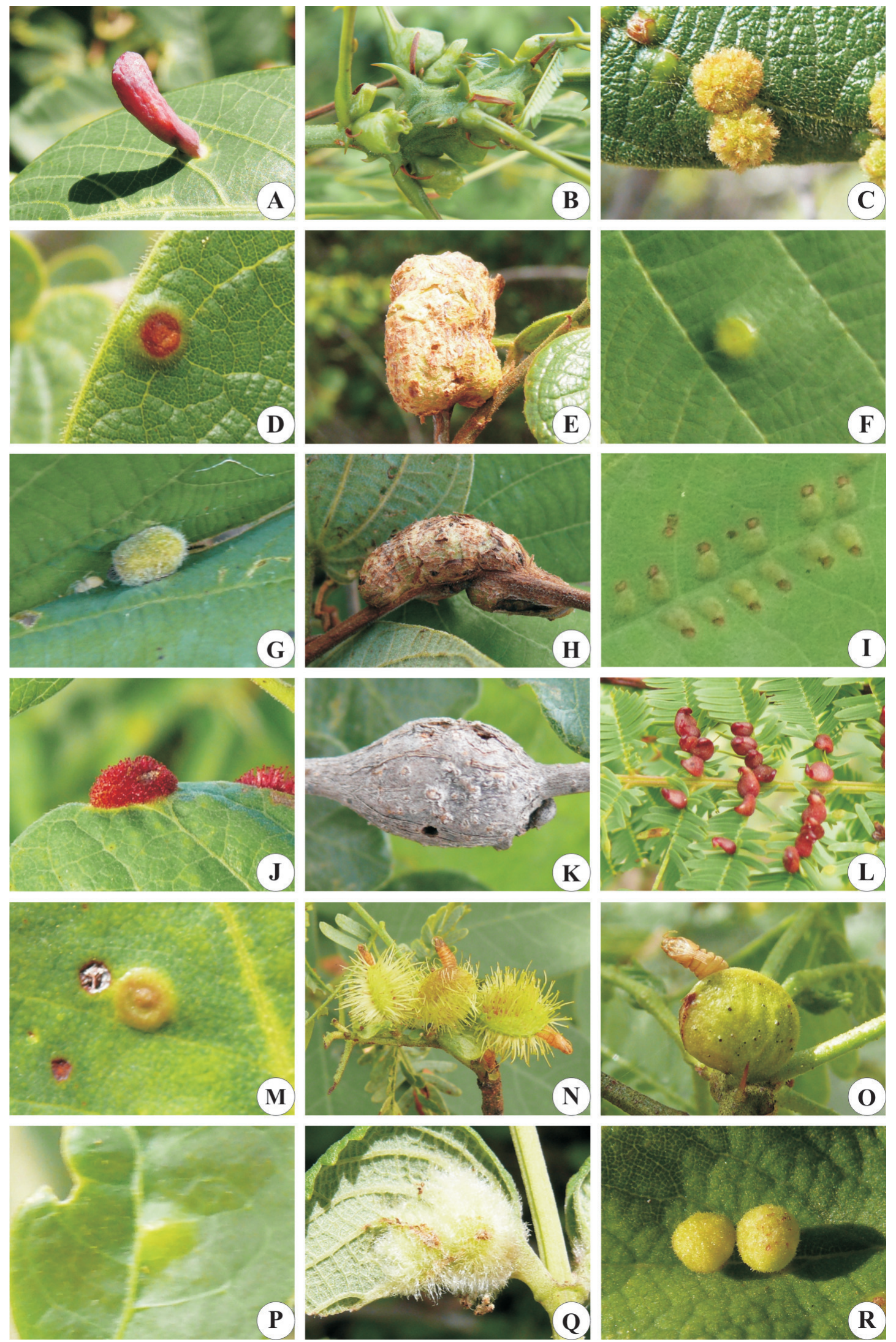

Fig. 3. Galling insect morphospecies in caatinga of Pernambuco, Brazil. A - Manihot dichotoma; B - Acacia sp.; C-E - Bauhinia acuruana; F-I Bauhinia cheilantha; J-K - Caesalpinia bracteosa; L - Fabaceae sp. 1; M-Hymenaea cf. eriogyne; $\mathrm{N}-\mathrm{O}$-Mimosa tenuiflora; $\mathrm{P}$-Piptadenia moniliformis; Q-R - Hyptis sp. For host plant identification and gall morphotypes description, see also Table I. 

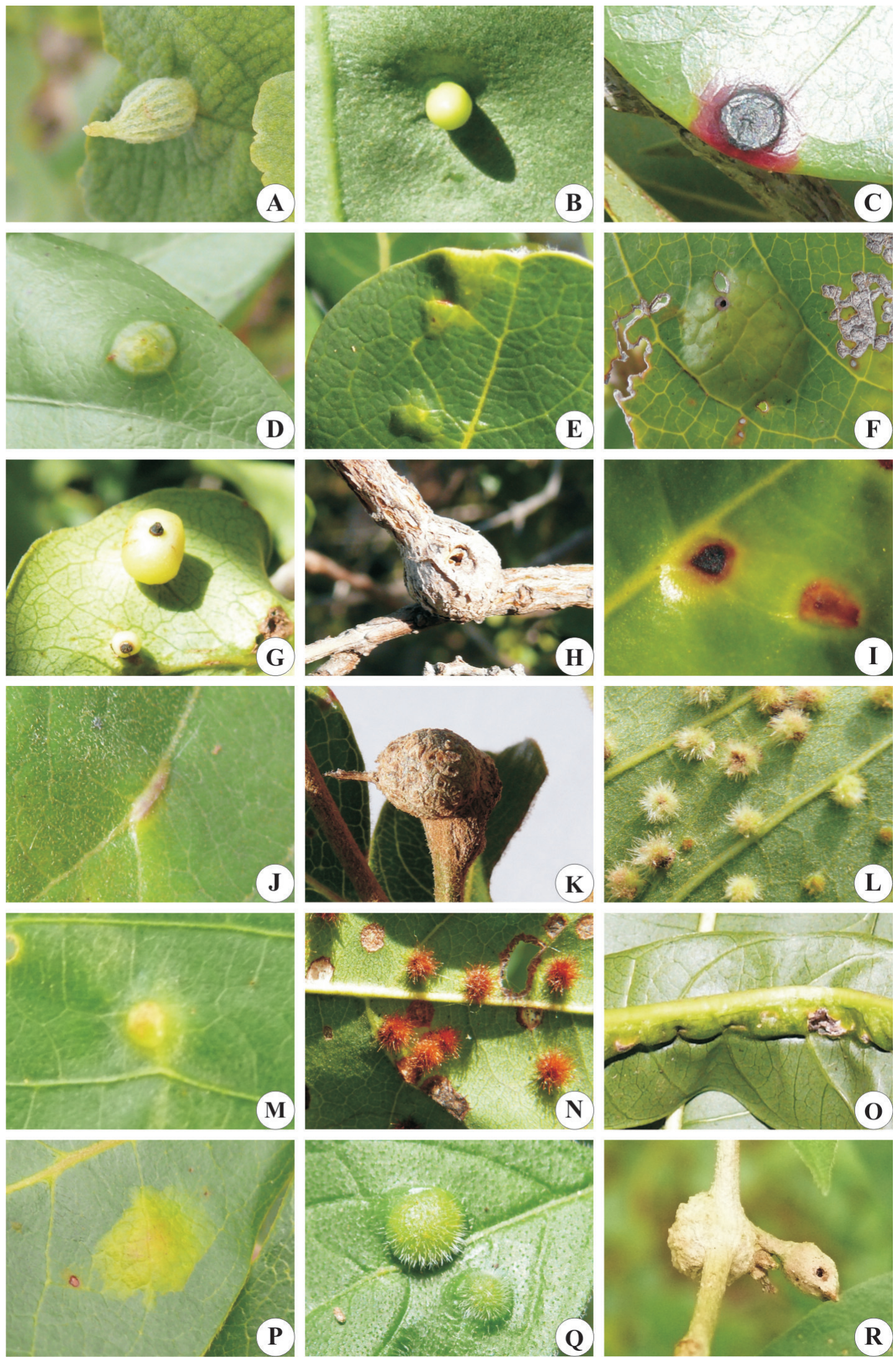

Fig. 4. Galling insect morphospecies in caatinga of Pernambuco, Brazil. A - Hyptis sp.;B - Phthirusa pyrifolia; C - Byrsonima gardneriana; D Byrsonima intermedia; E - Byrsonima sp.; F - Heteropterys cf. anoptera; G - Eugenia $\mathrm{cf}$. punicifolia; $\mathrm{H}$ - Myrtaceae sp. 1; I - Myrtaceae sp. 2; J Psidium guineensis; $\mathrm{K}$ - Guapira laxa; $\mathrm{L}$ - Phytolacca $\mathrm{cf}$. thyrsiflora; $\mathrm{M}$ - Serjania glabrata; $\mathrm{N}$ - Talisia esculenta; $\mathrm{O}$ - Chrysophyllum gonocarpum; $\mathrm{P}$

- Manilkara dardanoi; Q-R - Solanaceae sp. 1. For host plant identification and gall morphotypes description, see also Table I. 

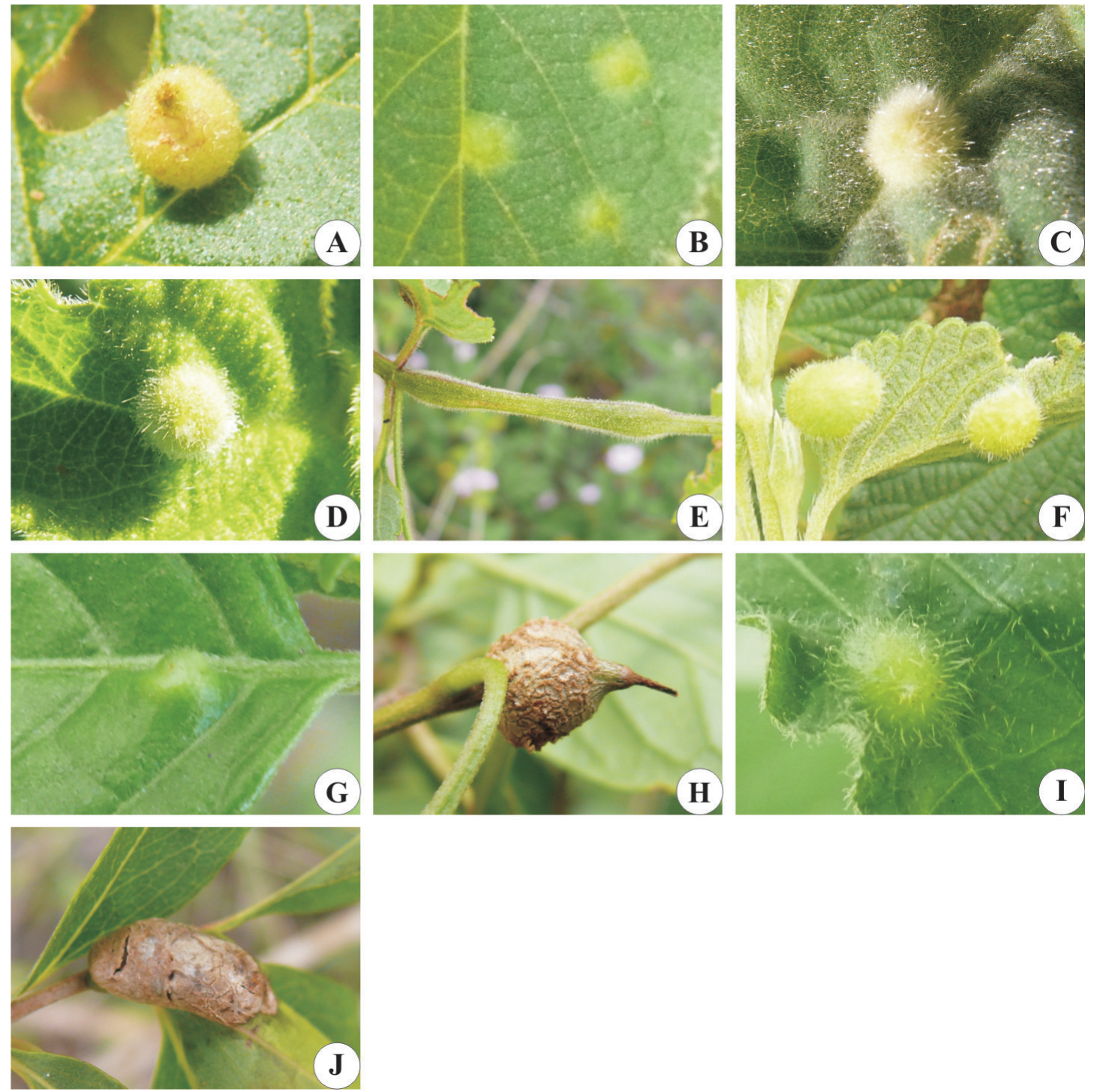

Fig. 5. Galling insect morphospecies in caatinga of Pernambuco, Brazil. A - Solanum cf. paludosum; B - Helicteres velutina; $\mathrm{C}-$ Waltheria indica; $\mathrm{D}-\mathrm{E}$ - Lantana camara; F - Lippia gracilis; G-H - Not identified sp. 1; I - Not identified sp. 2; J - Not identified sp. 3. For host plant identification and gall morphotypes description, see also Table I.

\section{DISCUSSION}

Most studies conducted in Brazil with description of insect galls are concentrated in the cerrado (savanna) (e.g., Fernandes et al. 1997; Gonçalves-Alvim \& Fernandes 2001a, b; Lara et al. 2002; Urso-Guimarães et al. 2003; Maia \& Fernandes 2004; Urso-Guimarães \& Scarelli-Santos 2006; Carneiro et al. 2009b; Coelho et al. 2009) and this one represents the first contribution o the understanding on this guild distribution and diversity in the caatinga vegetation. Based on the present results of galling insects and their host plants in the caatinga we attempt some generalizations. The low richness of galling species in the caatinga (64 morphospecies) was more similar with the seasonally dry tropical forest in Serra do Cipó located in the southern range of the Espinhaço Mountains, which investigators found 92 distinct gall morphotypes on several organs of 51 host plant species of 19 families (Coelho et al. 2009). However, this comparison is not conclusive because in another dry forest of northern Minas Gerais (Jequitinhonha Valley), Fernandes et al. (1997) reported 236 species of galling insects. A comparison with the data from another Brazilian ecosystems (Atlantic rain forest, cerrado, Amazon rain forest), indicates that the richness of the insect galls in the caatinga is comparatively smaller. The richness of galling species in the Atlantic rain forests of the Vale do Rio Doce was represented by 273 galling species (Fernandes et al. 2001), and in the central Amazonia, Julião et al. (2005) reported on 246 and 302 galls morphotypes on the canopy of a seasonally flooded forest of igapo and varzea, respectively. It is clear in these comparisons that we need more data on the caatinga and on others wet and dry tropical forests in a near future to better understand the evolution and 
biogeography of galling insects in Brazil, and to construct a general pattern of species richness.

Different hypotheses have been proposed to explain variation in abundance and diversity of galling species. According to Fernandes \& Price (1988, 1991, 1992), the harsh environment hypothesis predicts that galling species richness will be higher in dry and hygrothermically stressed environments, and in Brazil, based on this hypothesis, the caatinga had higher richness than other wet ecosystems. Preliminary, our results not corroborated this hypothesis because that caatinga was poorer in species of galling insects than other areas; however, this hypothesis must be tested further. One study supports a low diversity of galling insects in dry forest (29 galling species in an Argentinean Chaco, semi-arid region very similar to caatinga, see Fernandes et al. 2002; and 92 galling species in dry forest of cerrado, see Coelho et al. 2009).

Although the purpose of this study is not to compare the richness of galling insects among sample areas, it is important to emphasize that the Vale do Catimbau showed approximately half (33 morphotypes) of all species found in this survey. This pattern could be produced by the atypical vegetation of this valley, whose revealed a plant species pattern different from those of the caatinga in Northeastern Brazil, with part of its flora presents the geographical distribution covering open vegetation formations such as cerrado, rupestrian fields and others (see Rodal et al. 1998).

This is the first study on galling insect richness done in the caatinga. However, other caatinga areas, in other Brazilian states should be sampled in order to reach a better understanding of the distribution of galling insects and their host plants along the gradient of this dry forest due to the territorial extension of this semi-arid vegetation. This study constitutes a unique data set that reinforce the need to survey in tropical dry forests to better comprehend gall-forming insect distribution patterns.

\section{ACKNOWLEDGMENTS}

We thank M. A. A. Carneiro and two anonymous reviewers for comments of this manuscript. We also thank Mr. Gilcean for field work, A. Aguiar (Patriota) for figure design, and the support provided by DCR-FACEPE/CNPq (DCR-0087-2.05/ 06, APQ-0008-2.05/07), FAPEMIG (APQ-01278-08, CRA 465/07, 122/07) and CNPq (309633/2007-9).

\section{REFERENCES}

APGII. 2003. An update of the Angiosperm phylogeny group classification for the orders and families of flowering plants: APGII. Botanical Journal of the Linnean Society 141: 399-436.

Carneiro, M. A. A.; C. S. A. Branco; C. E. D. Braga; E. Almada; M. B. M. Costa, G. W. Fernandes \& V. C. Maia. 2009a. Are gall midge species (Diptera, Cecidomyiidae) host plant specialists? Revista Brasileira de Entomologia 53: 365-378.

Carneiro, M. A. A.; R. A. X. Borges; A. P. A. Araújo \& G. W. Fernandes. 2009b. Insetos indutores de galhas da porção sul da Cadeia do Espinhaço, MG, Brasil. Revista Brasileira de Entomologia 53: 570-592.
Castelletti, C. H. M; Santos A. M. M.; Tabarelli M. \& J. M. C. Silva. 2003. Quanto ainda resta da caatinga? Uma estimativa preliminar, p. 719734. In: I. Leal; M. Tabarelli \& J. M. C. Silva (eds.). Ecologia e Conservação da Caatinga. Recife, Editora Universitária da Universidade Federal de Pernambuco, 804 p.

Coelho, M. S; E. Almada; G. W. Fernandes; M. A. A. Carneiro; R. M. Santos, A. V. Quintino \& A. Sanchez-Azofeifa. 2009. Gall inducing arthropods from a seasonally dry tropical forest in Serra do Cipó, Brazil. Revista Brasileira de Entomologia 53: 404-414.

Cuevas-Reyes, P.;Quesada, M.; Hanson, P.; Dirzo, R. \& K. Oyama. 2004. Diversity of gall-inducing insects in a Mexican tropical dry Forest: the importance of plant species richness, life forms, host plant age and plant density. Journal of Ecology 92: 707-716.

Espírito-Santo, M. M. \& G. W. Fernandes. 2007. How many species of gall-inducing insects are there on earth, and where are there? Annals of the Entomological Society of America 100: 95-99.

Fernandes, G. W. \& D. Negreiros. 2006. A comunidade de insetos galhadores da RPPN Fazenda Bulcão, Aimorés, Minas Gerais, Brasil. Lundiana 7: $111-120$.

Fernandes, G. W. \& P. W. Price. 1988. Biogeographical gradients in galling species richness: tests of hypotheses. Oecologia 76: 161-167.

Fernandes, G. W. \& P. W. Price. 1991 Comparison of tropical and temperate galling species richness: the roles of environmental harshness and plant nutrient status, p. 91-115. In: P. W. Price; T. M. Lewinsohn; G. W. Fernandes \& W. W. Benson (eds.). Plant-animal interactions: evolutionary ecology in tropical and temperate regions. New York, John Wiley, xiv+639p.

Fernandes, G. W. \& P. W. Price. 1992. The adaptive significance of insect gall distribution: survivorship of species in xeric and mesic habitats. Oecologia 90: 14-20.

Fernandes, G. W.; G. R. Julião; R. C. Araújo; S. C. Araújo; J. A. Lombardi; D. Negreiros \& M. A. A. Carneiro. 2001. Distribution and morphology of insect galls of the Rio Doce Valley, Brazil. Naturalia 26: 211-244.

Fernandes, G. W.; O. Varela; E. H. Bucher; J. M. Chani; A. L. Echevarria; M. M. Espírito-Santo; J. Lima; D. Negreiros \& C. S. Toledo. 2002. Gall-forming insects on woody and herbaceous plant species of the semi-arid chaco forest, Argentina. Lundiana 3: 61-66.

Fernandes, G. W.; R. C. Araújo; S. C. Araújo; J. A. Lombardi; A. S. Paula; R. Loyola Júnior \& T. G. Cornelissen. 1997. Insect galls from savanna and rocky fields of the Jequitinhonha Valley, Minas Gerais, Brazil. Naturalia 22: 221-244.

Gonçalves-Alvim, S. J. \& G. W. Fernandes. 2001a. Biodiversity of galling insects: historical, community and habitat effects in four neotropical savannas. Biodiversity and Conservation 10: 79-98.

Gonçalves-Alvim, S. J. \& G. W. Fernandes. 2001b. Comunidades de insetos galhadores (Insecta) em diferentes fisionomias do cerrado em Minas Gerais, Brasil. Revista Brasileira Zoologia 18: 289-305.

Julião, G. R.; E. M. Venticinque \& G. W. Fernandes. 2005. Richness and abundance of gall-forming insects in the Mamirauá Várzea, a flooded Amazonian forest. Uakari 1: 39-42.

Julião, G. R.; M. E. C. Amaral \& G. W. Fernandes. 2002. Galhas de insetos e suas plantas hospedeiras no Pantanal Pantanal Sul-Matogrossense. Naturalia 27: 47-74.

Julião, G. R.; M. E. C. Amaral; G. W. Fernandes \& E. G. Oliveira. 2004. Edge effect and species-area relationships in the gall-forming insect fauna of natural forest patches in the Brazilian Pantanal. Biodiversity and Conservation 13: 2055-2066.

Lara, A. C. F. \& G. W. Fernandes. 1996. The highest diversity of galling insects: Serra do Cipó, Brazil. Biodiversity Letters 3: 111-114.

Lara, A. C. F.; G. W. Fernandes \& S. J. Gonçalves-Alvim. 2002. Tests of hypotheses on patterns of gall distribution along an altitudinal gradient. Tropical Zoology 15: 219-232.

Leal I. R.; J. M. C. Silva; M. Tabarelli \& T. E. Lacher. 2005. Changing the course of biodiversity conservation in the caatinga of northeastern Brazil. Conservation Biology 19: 701-706.

Maia V. C. \& G. W. Fernandes. 2004. Insect galls from Serra de São José (Tiradentes, MG, Brazil). Revista Brasileira de Biologia 6: 423-445. 
Maia, V. C.; G. W. Fernandes; H. Magalhães \& J. C. Santos. 2010. Two new species of Lopesia Rübsaamen (Diptera, Cecidomyiidae) associated with Mimosa hostilis (Mimosaceae) in Brazil. Revista Brasileira de Entomologia 54: 578-583.

Mendonça, M. S. 2007. Plant diversity and galling arthropod diversity searching for taxonomic patterns in an animal-plant interaction in the neotropics. Boletín Sociedad Argentina Botánica 42: 347-357.

Moreira, R.G.; G.W. Fernandes; E. D. Almada \& J. C. Santos. 2007. Galling insects as bioindicators of land restoration in an area of Brazilian Atlantic Forest. Lundiana 8: 107-112.

Oliveira, J. C. \& V. C. Maia. 2005. Ocorrência e caracterização de galhas de insetos na restinga de Grumari (Rio de Janeiro, RJ, Brasil). Arquivos do Museu Nacional 63: 669-675.

Prado, D. E. 2003. As caatingas da América do Sul, p. 3-73. In: I. Leal; M. Tabarelli \& J. M. C. Silva (eds.). Ecologia e Conservação da Caatinga. Recife, Editora Universitária da Universidade Federal de
Pernambuco, xvi+822 p.

Price, P. W.; G. W. Fernandes; A. C. F. Lara; J. Brawn; D. Gerling; H. Barrios; M. G. Wright; S. P. Ribeiro \& N. Rothcliff. 1998. Global patterns in local number of insect galling species. Journal of Biogeography 25 : 581-591.

Rodal, M. J. N.; K. V. A. Andrade; M. F. Sales \& A. P. S. Gomes. 1998. Fitossociologia do componente lenhoso de um refúgio vegetacional no município de Buíque, Pernambuco. Revista Brasileira de Biologia 58: $517-526$.

Urso-Guimarães, M. V. \& C. Scarelli-Santos. 2006. Galls and gall makers in plants from the Pe-Gigante Cerrado Reserve, Santa Rita do Passa Quatro, SP, Brazil. Brazilian Journal of Biology 66: 357-369.

Urso-Guimarães, M. V.; C. Scareli-Santos \& A. C. Bonifácio-Silva. 2003. Occurrence and characterization of entomogen galls in plants from natural vegetation areas in Delfinópolis, MG, Brazil. Brazilian Journal of Biology 63: 705-715. 